\title{
Changes and Transformations of the Spatial Structure and Landscape in the Area of L'Aquila between the Fourth and Eighth Centuries AD
}

\author{
Fabio Redi \\ Università degli Studi dell'Aquila, Department of Humanities \\ fabio.redi@cc.univaq.it
}

\begin{abstract}
In the period between Late Antiquity and the Early Middle Ages, the territory of L'Aquila underwent a number of transformations that also occurred elsewhere. The cities (Amiternum, Civita di Bagno, Peltuinum, Aufinum) suffered a heavy setback in their urban and economic development because of the general crisis of the Empire, the devastating effects of earthquakes in the second half of the fourth century, the Greek-Gothic war, the barbarian migrations and last, but not least, the changes in society and the ideological-cultural transformation induced by Christianisation. The relationship between town and country / city and territory undergoes fundamental changes, with different connotations in terms of landscape and settlements. The archaeological research and excavation of the surface, which we have carried out in the territory of L'Aquila for over a decade, is beginning to provide evidence of the results of the urban and rural landscape transformations: the Christianisation of space and functional transformation of major public and private facilities are confirmed by the discovery of churches replacing temples, as in Centurelli and in Piana San Marco and so on. Other evidence is provided by citadels obtained through the restoration of theatres and amphitheatres or city gates, as in the restorations and transformations of Peltuinum and Amiternum. We can also mention functional transformations such as private domus, sometimes with a long occupation of public spaces, such as in Amiternum and Peltuinum, or the defunctionalisation of infrastructures such as thermal complexes, roads, aqueducts and sewers. Homes or wooden cabins occupy the scene in the Amiternum thea-
\end{abstract}

tre; churches like Santa Maria of Ansedonia abut the city walls. The rural landscape is changing for many reasons: the spread of Christian places of worship, the collapsing of public infrastructures such as roads or waterways, the advancement of wetlands and uncultivated areas and grazing activities to the detriment of agricultural areas. By the seventh century there is a further change in urban and agro-pastoral planning, which will be illustrated with concrete examples provided by the archaeological research we are carrying out.

Keywords: L'Aquila, Changes and Transformations, Settlement Patterns, Landscapes, FourthEighth Centuries AD

\section{The Cities}

\section{a) Amiternum}

Our recent archaeological excavations in the area of the primitive cathedral of Santa Maria in Civitate, in the area of Campo Santa Maria, are providing useful information, despite their incompleteness, on the continuity of settlement, at least in the area of the ancient city from the second to the thirteenth century. This puts back by at least four centuries what had been considered the proof of the abandonment of the city: the visit by Deoderico, bishop of Metz, around AD 970 (Redi et al, 2013; Redi et al, in press). (fig. 1)

The bishop, appointed by the Emperor to collect relics, arrived in Amiternum and described the city as a distressing pile of ruins. The truth is that the site occupied by a prestigious domus of the Early Imperial period was restored between the fourth 


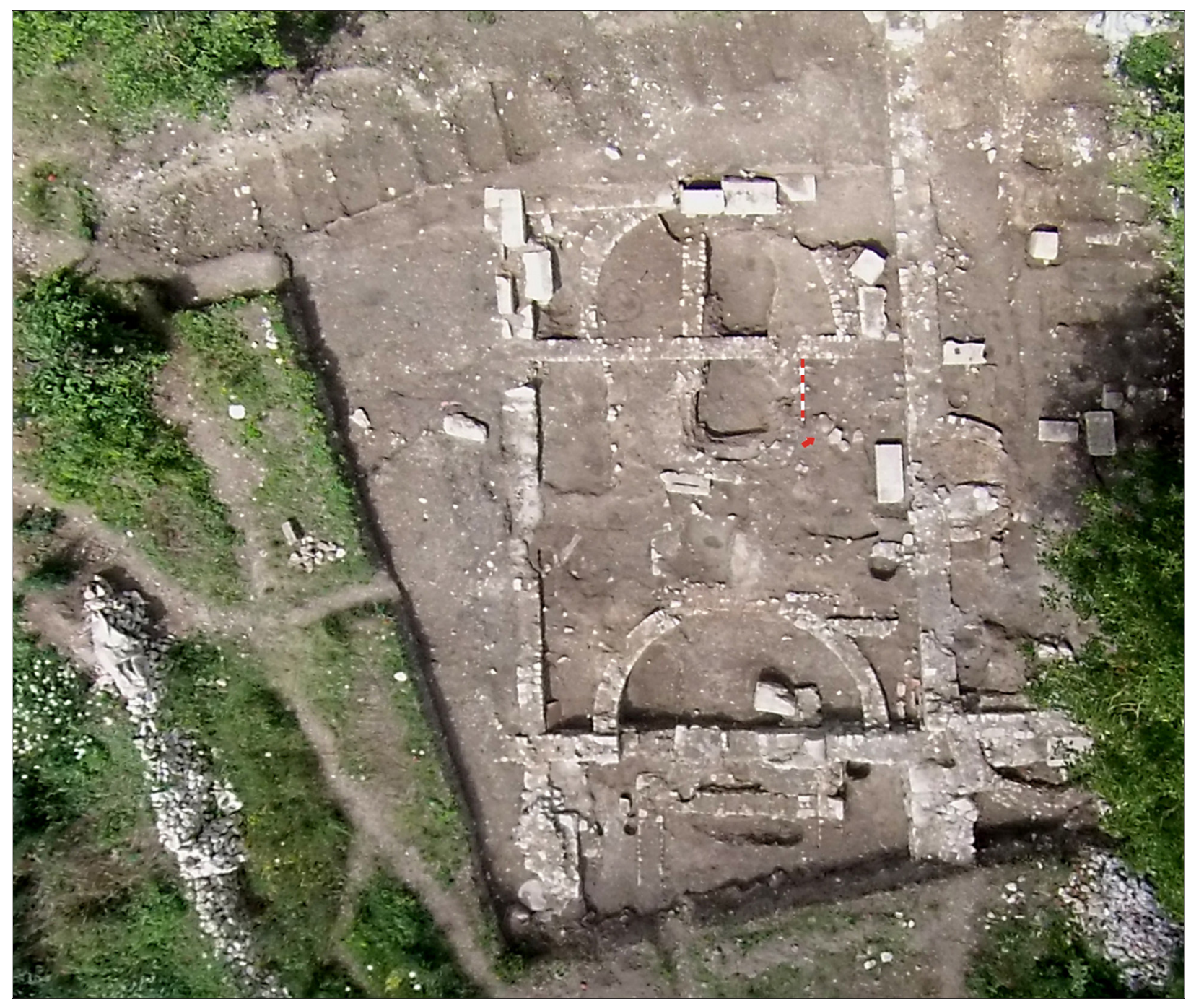

Fig. 1. Amiternum "Campo Santa Maria”, aerial view of the excavation.

and fifth centuries after a brief abandonment, probably caused by the earthquake in AD 346. It was rebuilt with the inclusion of a space for the Christian cult, with a semi-circular apse covering part of its western wall. This ecclesiastic structure can be dated between the fifth and the sixth centuries, during the time of the bishop of Amiternum Valentino or his successor Castorio, contemporary to Equizio, founder of a pre-Benedictine monastic movement and shortly after the monumentalisation of the martyr Vittorino's tomb wanted by Bishop Quodvultdeus (Giuntella, 1994; 1999; 2001; 2002; 2003; Pani Ermini, 1972; 1975; 1979; 1987;
Redi, 2009; Somma, 2012). (fig. 2)

A large semi-circular apse of a three-aisled building stands against the southern side wall of the rectangular space with an E-W orientation. The aisled building follows a N-S orientation and is dated to the Lombard period, when the bishop of Amiternum was Ceteo, martyred between 590 and 604. With Ceteo the series episcoporum of Amiternum was interrupted but not the activity within the ecclesiastic structure, probably a cathedral, which revealed signs of the renovation of the liturgical decorations of the rebuilt choir plutei, similar and contemporary to the ones not far away in the catacombs of San Vittorino (Pani Ermini, 1976; 1978; Redi \& Savini, in press).

These, just like the insula episcopalis that we mentioned, had modified the urban setting from 


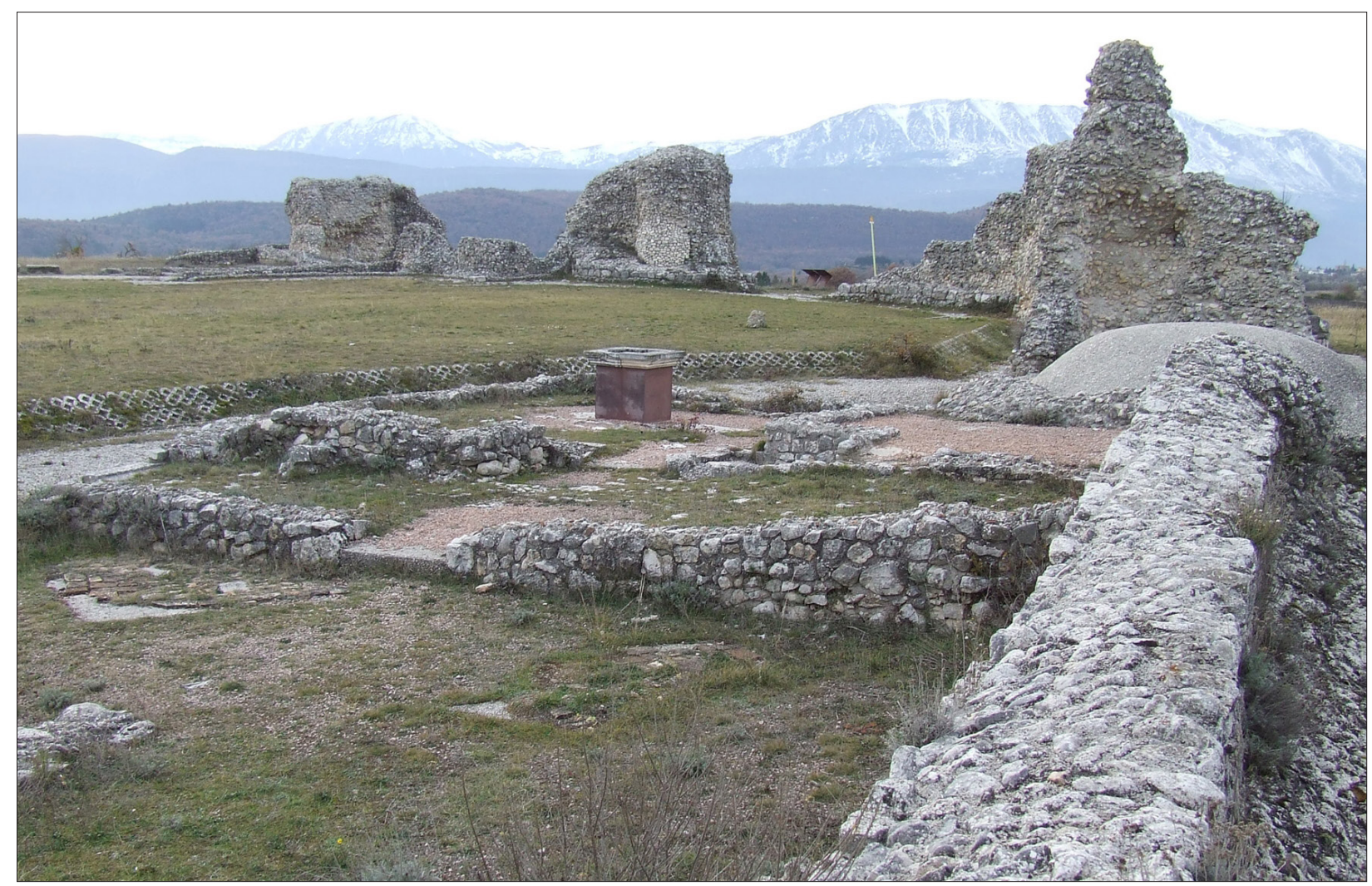

Fig. 2. Peltuinum, church of Santa Maria di Ansidonia, partially leaning against a segment of the Roman walls.

as early as the third-fourth century by creating a new point of reference, like a sanctuary, a visual and directional goal for the Late-Antique and Early Medieval settlement, by attracting the cult of $\mathrm{Ob}$ servants and the euergetism of ecclesiastics and by Lombard aristocracy. As previously mentioned, during the fifth century, the Bishop Quodvultdeus monumentalized the tomb of the martyr Vittorino and built in front of it, in the same catacomb, a small single-aisle basilica with apse, a sort of martyrium, for the cult of the Saint. At a later date the local Lombard aristocracy positioned its family burials in this same space and enriched the building with reliefs typical of the same period as the plutei of the church built over the catacomb and dedicated to Saint Michael Giuntella, 2002; Pani Ermini, 1975; 1979; 1987; Redi, de lure \& Di Blasio, 2012; Redi, de lure \& Siena, 2012; Somma, 2012).

The urban setting of Amiternum appears to also be modified by the spoliation of public buildings, in addition to the creation of new Christian ecclesiastic points of reference and the architectural reuse of Patrician domus, like the one with peristilium close to the amphitheatre, where a copper medallion with a Christ monogram was found (Clementi, 2003; Pani Ermini, 1987; Redi \& Savini, in press; Scrinari, 1978). Structures became quarries for building materials such as columns, capitals, friezes, etc. for the construction of religious buildings, and new structures created in perishable materials such as clay and wood occupied the area of the collapsed or transformed ones llike close to the steps of the theatre), as a proof of the significant cultural and functional changes of the previous urban setting (Tuteri, 2014). Also the urban road network was damaged, due to the spoliation of residential buildings and the digging of burials in tombs that were excavated, removal of pavers, collapse of buildings and the rough restorations of different levels in the streets.

But what was happening in other cities of the territory, such as Peltuinum and Civita di Bagno-Forcona, in the same period? 


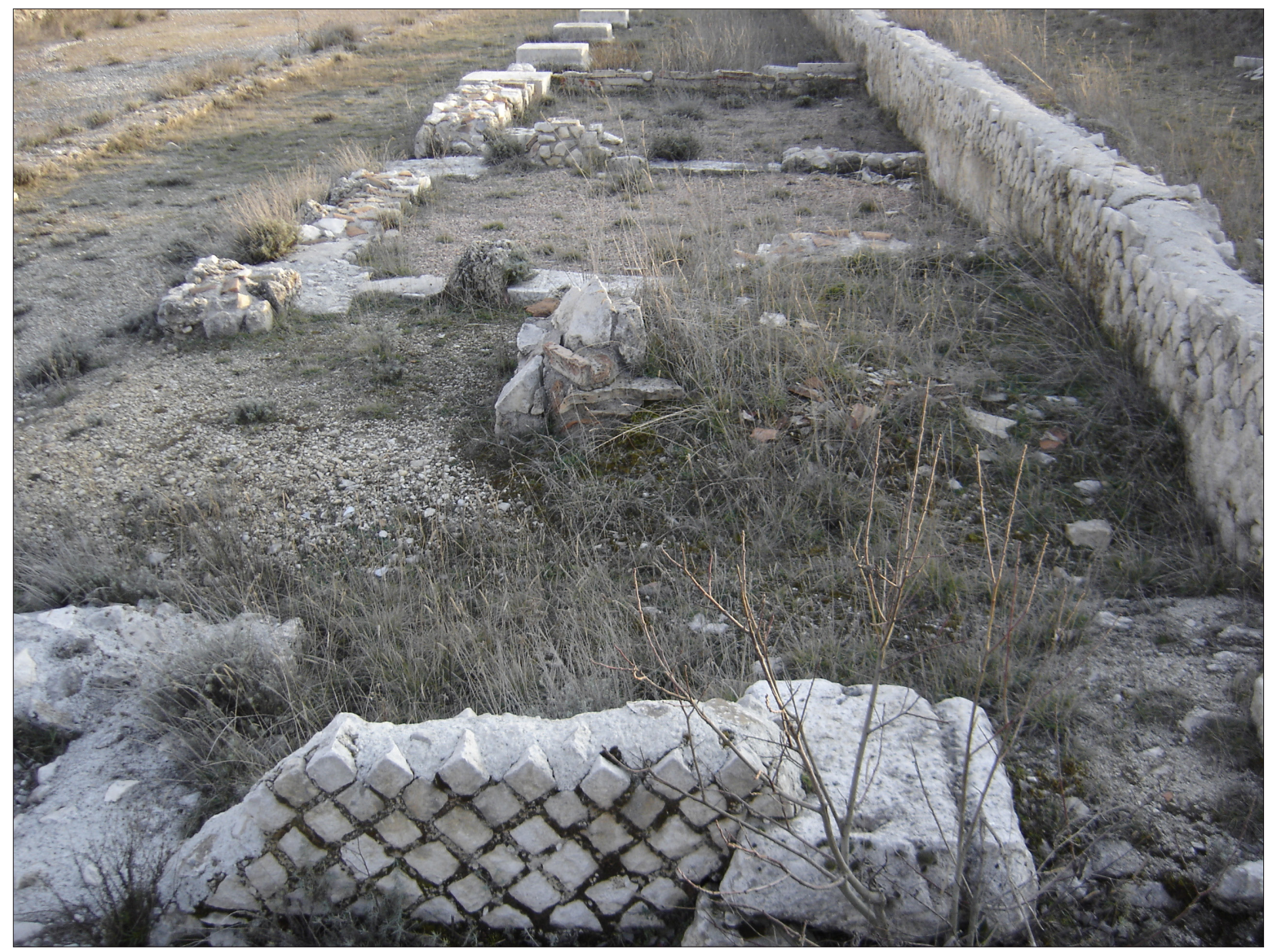

Fig 3. Peltuinum, reuse of the structures of the portico.

\section{b) Peltuinum}

As revealed by the series of archaeological excavations conducted by the archaeological Soprintendenza and Sapienza Università di Roma, the situation was not so different from the one described in Amiternum. Public buildings were spoliated and readapted to different functions; Christian cult buildings occupied relevant positions next to gatehouses and defensive walls, inside and outside of the urban precinct (Campanelli, 1996; Clementi, 2007; Redi, de lure \& Di Blasio, 2012; Redi, de lure \& Siena, 2012; Redi \& Savini, in press).

Some milestones found close to the main road axis of the city, identified with the Via Claudia Nova still in use at that time, were dated to the fourth century, so to the Late-Antique period. The earthquake of AD 346, despite its destructiveness evident from the signs of collapse of a porch wall in the temple of Apollo, did not determine the end of the city. It continued to survive, even if with evident reductions and transformations, for another seven centuries until the fourteenth century, when the city of L'Aquila rose (Redi 2009; Redi, de lure \& Siena, 2012; Tartara, 2007).

In the post-Constantine period some residential spaces were restructured, with the use of spolia from the Republican period, while the tabernae used for the assistance of travellers along the axis of the main road show signs of continuous use until the fifth century, although the buildings were restored and readapted. After all, as noticed in previous papers, the place-name Ansidonia acquired by Peltuinum during the Middle Ages, is a clear sign of the continuity of life in the city, despite its transformations and readaptations, in 
the Byzantine period. This means that, like the city with the same name in Tuscany on the Argentario, Ansidonia was used for the stockpiling of food and grains most likely for the Byzantine troops during the Greek-Gothic war. The term "Ansidonia" probably derives from the Greek "Sitòn" (Patitucci, 2001; 2004a; 2004b; Redi, de lure \& Siena, 2012; Tulipani, 1996).

The filling of the colonnade and the finding of a monolith, with the typical carving of an " $\mathrm{H}$ " next to a circular incision, in the southern part of the porch in the temple of Apollo, provide further proof of the activity of spoliation and readaptation of the urban setting. The monolith, like in other areas of the same territory and with strong comparisons with similar phenomena in Vandal North Africa, not absolutely identifiable with sacrifice altars, is part of a fundamental element of the prelum of an olive or grape press. Between the fifth and sixth centuries, this kind of press was installed into defunctionalised cultural or public buildings (Milanese, 2003).

While the dating of the restorations and consolidation of the theatre is uncertain and is generally identified with the Early Medieval period and with Lombard activities in cities connected to the placename "Parlascio" (Garzella, 1990), the building of a church identified as Santa Maria di Ansidonia can surely be associated to the Byzantine period (fifthsixth centuries). The building presented a group of burials positioned against the city walls and the eastern gatehouse which could be dated by their grave goods (Giustizia, 2007; Redi, de lure \& Siena, 2012). (fig. 3)

After all, the early Christianisation of the city, for which no mention of a bishop has been found, is documented by the finding of a bronze ring with a typical christogram Chi Rho dated to the fourth century near the porch of the temple of Apollo. Harder to date is the Christian epigraph reused in the southern wall of the church of San Paolo, located outside of the city walls and west of the theatre (Giustizia, 2007).

In the structures of the church, essentially relatable to a twelfth-thirteenth century building, are included some sculptural fragments dated to the eighth-ninth century belonging to a previous ecclesiastic Early Medieval building (Giustizia, 2007; Redi, 2010). Also in the same period, the existence of a Curtis S. Angeli is documented, belonging in 787 to a Lombard skuldheis named Scaptulus probably buried in a cemetery close by where a small golden cross (published by Rotili) was found (Redi, de lure \& Siena 2012; Rotili 1992-1993). In the eighth century, the Lombards had therefore constituted a skuldheis, that is a district composed of military units (or arimanni) established in strategic positions as Ansidonia had been for the Byzantines. The Curtis S. Angeli of Scattulo, described as a property of the abbey of Farfa in 888, also had an agricultural function, for the tillage of uncultivated lands or forests and for cultivation or pasture activities.

An urban landscape, by now largely de-structured, dispersed and rural, characterized the territory of Peltuinum in what had once been a flourishing city.

\section{The Relationship between the Urban/ Rural Context and Road Network: the "Paganico-Vicano" and "Plebano" Systems}

As for the cities, vici and pagi transformed during the Early Middle Ages and defined new territorial settings as a consequence of the phenomenon of Christianisation, the pressure of Barbarian migrations and the settlement of new cultural and ethnic groups. The data provided by two of our archaeological excavations, conducted in Barete la few kilometres from Amiternum) and Piana San Marco (in the surroundings of a pagus at 1100 metres a.m.s.l. on the Gran Sasso Mountain), contribute to our knowledge of this process of territorial transformation.

\section{a) Pieve of San Paolo di Barete}

The Christianisation of the city of Amiternum happened early, as revealed by the artefacts studied 


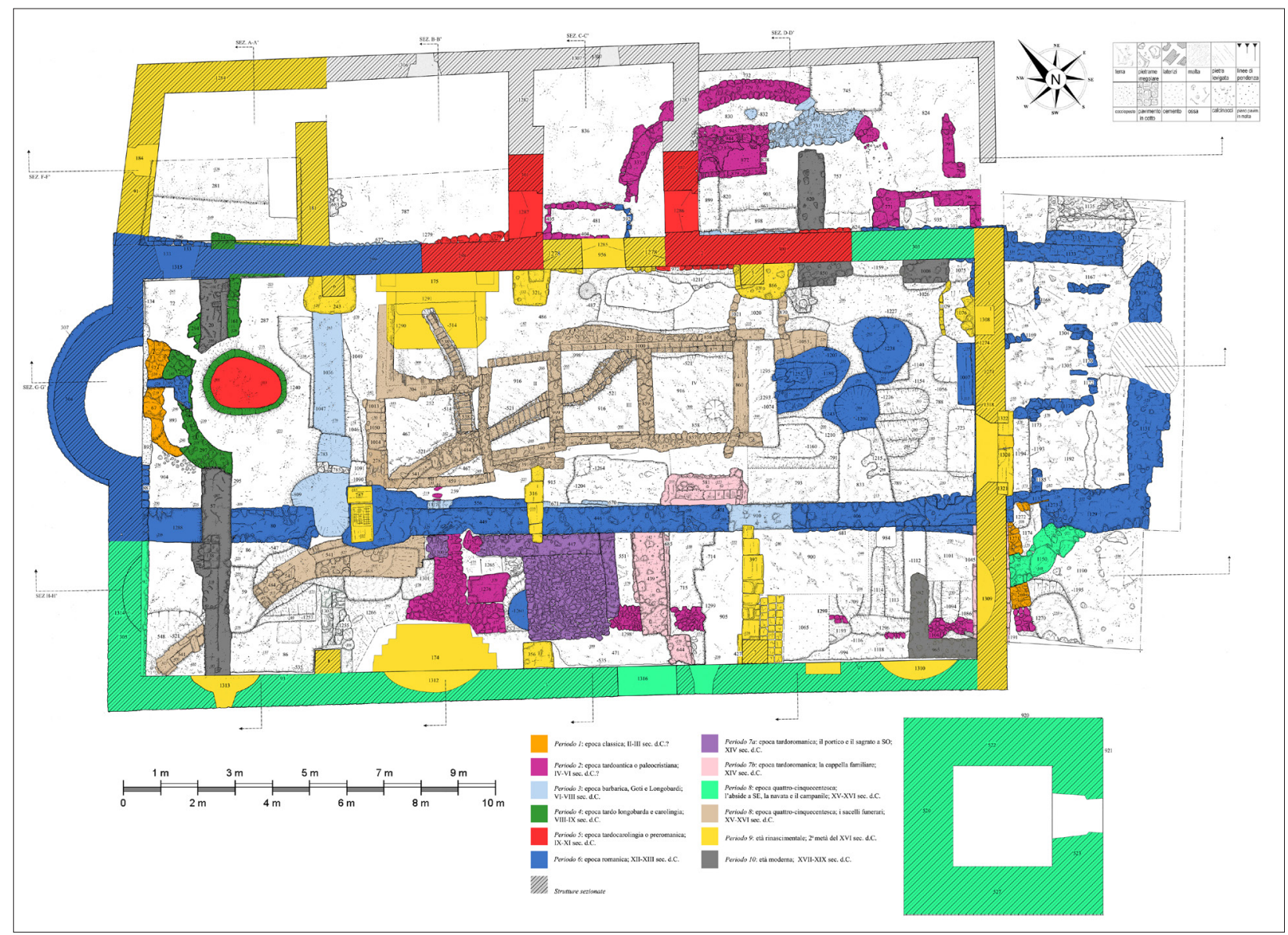

Fig. 4. Barete, church of San Paolo, general plan of the excavation.

by Bevignani and Scrinari and the presence of the catacombs of San Vittorino and the early Christian cathedral found by us. We can attest to the rapid spread of Christianisation in the surrounding territory also.

The cemetery of the pagus of Labaretum, only four kilometres NW of Amiternum, received the burial of Domitilla, daughter of the Emperor Vespasian, converted to Christianity by Vittorino; a church with rectangular plan, oriented perpendicularly to the main axis, with a wide exedra between two tombs and with a shallow narthex on the façade, was built in the fifth-sixth century next to a tower or cubedshaped tomb dated to the second-third century. In the middle of the apse, between a baptismal font of the same period and the semicircular wall, a special burial pit was prepared, of an upper-class young boy las deduced from the find of a sixth century bone-comb in the burial) (Redi, 2007; 2009; Redi \& Forgione, 2014). (fig. 4)

Local aristocracy, perhaps Roman-Byzantine, lived in Barete in this period, but also influential characters of Ostrogoth origin were buried in Colle di Casciano in the area of Barete, as evident from the three fibulae, inlay worked with gold and gems, found in 1892 and kept in the museum of Villa Giulia in Rome (Antonelli \& Tornese, 2013; Redi \& Forgione, 2014).

Amphorae of the Late Roman Amphora 4 type, dated to the sixth century, found in Barete and Amiternum, attest to long-distance commerce in the Byzantine and then Lombard period. In the church of San Paolo di Barete the traces of a sixth to seventh or seventh to eighth century building with a simple rectangular plan next to a space with a baptismal font were found. The presence of a baptistery is particularly interesting since it proves that, with the transformation 


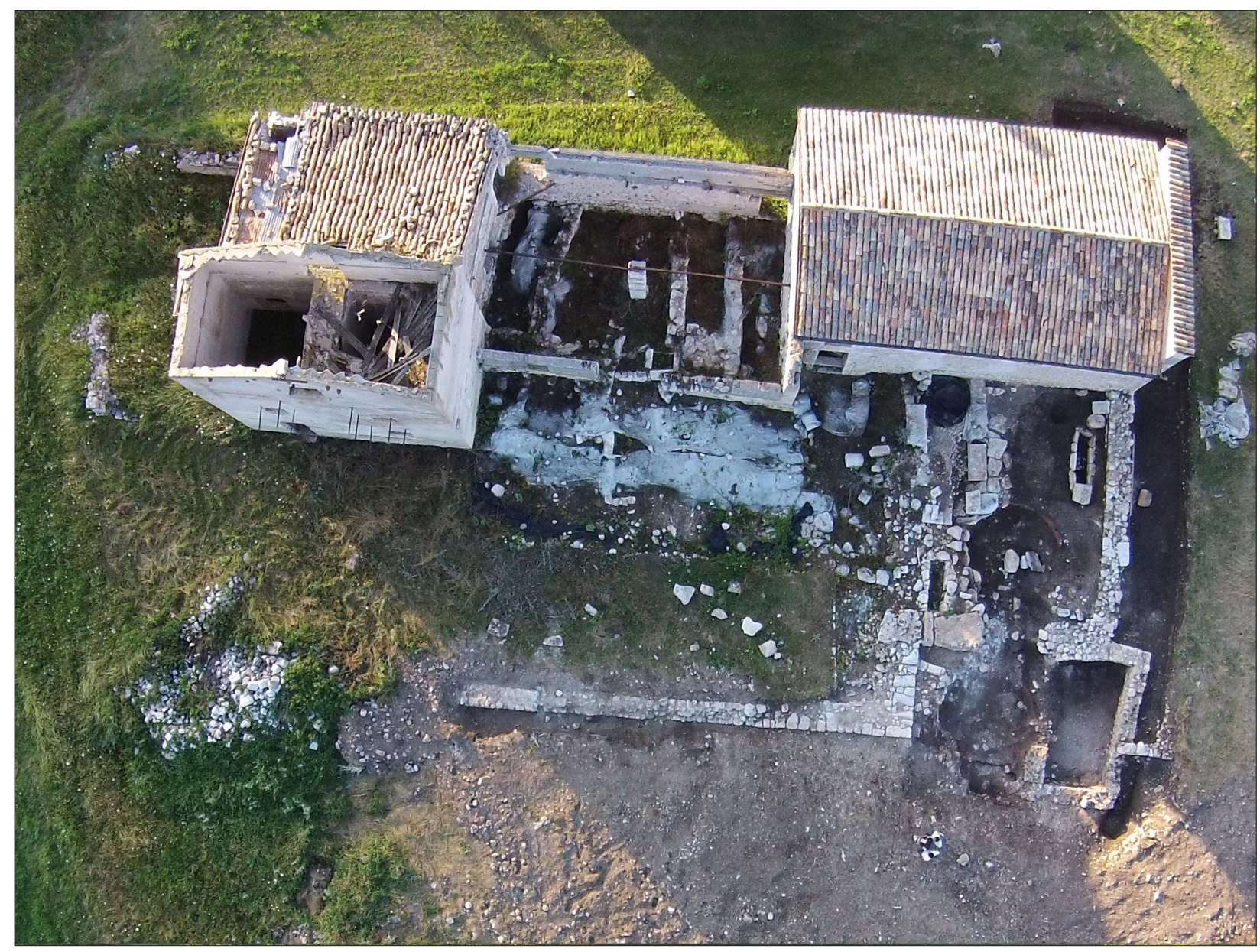

Fig. 5. Piana San Marco, aerial view of the excavation.

of the fifth-sixth century, the church acquired the function of cura animarum of the small settlements spread in the surrounding area. These settlements were clustered around small ecclesiae like San Mauro and Sant'Eusanio in Barete, dated at least to the seventh-eighth century (Redi et al, 2012).

The baptismal church of San Paolo has also revealed significant traces of an apsidal and frontal enlargement in the Carolingian period and of a remake of liturgical instruments by local workshops with the use of cartons from Spoleto, Teramo and Cividale del Friuli (Redi, 2010; Redi \& Forgione, 2014). Traces of the removal of a burial were found beneath the altar, belonging to the body of a Saint venerated within the church, as deduced from the location and ritual features.
The widespread dissemination of Christianity in the rural landscape took place thanks to particular sanctuarial nodes, positioned strategically along the Roman road network, still widely used. A proof of this is the monumentalisation of the catacombs of Santa Giusta of Bazzano, along the Claudia Nova about six kilometres south-east of L'Aquila, and of San Massimo of Aveia in the cathedral of Civita di Bagno in Forcona (Redi, 2007; Redi \& Savini, in press; Redi, de lure \& Di Blasio, 2012).

\section{b) Piana San Marco}

Once again the excavations revealed evidence of significant continuity (Redi, 2009; Redi \& lovenitti, 2006; Redi \& Malandra, 2004; Redi, de lure \& Siena, 2012). The pagus of Marcianisci, which had replaced the fortified Italic site of Colle della Battaglia, transferring the settlement almost to the centre of 
a fertile carsic sinkhole, was structured in a series of residential buildings belonging to a domus with farm and other auxiliary buildings. This can be understood through the interpretation of the cemetery and about forty of the epigraphs found there (published by Mommsen in CIL IX) coming from a pear-shaped Roman-Italic pit and from a temple, of which we found the podium and several architectural elements, such as columns, bases, fragments of frieze, etc. Our excavations have also brought to light Byzantine and Early Medieval structures, the auxiliary buildings of a monastic cell part of the monastery of San Vincenzo al Volturno, known from the ninth century, and a small church built over the podium of the Roman temple between the thirteenth and fourteenth centuries (fig. 5).

This was restructured in the Byzantine period and surrounded by walls without foundations, built with irregular-shaped stones and roughly bonded with low-quality mortar. These walls, built most likely as a fortification during the Greek-Gothic war, are dated both stratigraphically and by the find of a golden aureus of Justinian and six silver coins, an extraordinary treasure recovered in our excavations.

The site, besides being characterized by the presence of a sinkhole used for agricultural purposes (arable and forage) and surrounding hills, was also inhabited because it represented a strategic hub of the minor road network being crossed by commercial and military routes. This road network linked the Adriatic area to the high pasture lands of Gran Sasso across the Forca di Penne, in a period during which transhumance, at least vertical transhumance, had not ceased.

\section{c) Roundabout of S.S. 17 to Centurelli}

The reconstruction of the landscape made possible by the archaeological excavations conducted by the Soprintendenza Archeologica at the time of works on the SS 17 road confirms what has been previously established on the continuity of settlement patterns: Italic burials, Roman road networks and the podium of a destructured Roman temple (transformed into a church with sepulchre between the sixth to seventh and the twelfth centuries) and also the indications of abandonment both of the road network (obliterated by burials) and of structures for farming activities belonging to a mansio or hospitum along the road (showing signs of a later readaptation and reuse). (D'Ercole \& Martellone, 2007; Redi \& Savini, in press; Redi, de lure \& Siena, 2012).

\section{d) The mansio of Bazzano}

Again in this case the excavations conducted by the Soprintendenza Archeologica, at the time of the construction of a warehouse for the Akron corporation, uncovered the ruins of a mansio dated to the Republican period with signs of a later obliteration from five burials (with burial goods) in the fifth-sixth century. In this second phase, the colonnade dividing a rectangular space into two separate aisles was filled with several wall structures constructed from spolia (Martellone, 2007; Redi, de lure \& Siena, 2012; Redi \& Savini, in press). The interruption in excavations did not allow for the identification of the possible site of Christian cult, connected to the burials found land to a larger cemetery area). The probable transformation of the mansio into a hospitum with chapel and cemetery is evidence of the continuity of use of the local road network, most likely used for military and traffic purposes rather than commercial and farming activities as in the past.

\section{Conclusions}

It is therefore clear that the archaeological excavations conducted by different research institutions (Soprintendenza, Universities, etc.) are still too incomplete to give an exhaustive framework on the transformations of the territory of L'Aquila in the urban and rural context. The results of these excavations are, however, sufficient to confirm the general trends of settlement patterns and to delineate the transformations of urban and rural landscapes. 


\section{References}

Antonelli S \& M Tornese 2013: Schede di archeologia altomedievale in Italia. Abruzzo, Studi Medievali 3, 54 (1), 365-443.

Campanelli $A$, (ed.) 1996: Peltuinum, antica città sul tratturo, Carsa Edizioni, Pescara.

Clementi A, 2003: Amiternum dopo la distruzione, Libreria Colacchi, L'Aquila.

Clementi A, (ed.) 2007: I campi aperti di Peltuinum dove tramonta il sole, Deputazione Abbazia di Collemaggio, L'Aquila.

CIL IX = Corpus Inscriptionum Latinarum, Mommsen T (ed.), Berolini, 1883.

D'Ercole V \& A Martellone 2007: Nuove scoperte archeologiche nel territorio peltuinate, in Clementi A (ed.), I campi aperti di Peltuinum dove tramonta il sole: 567-81. Deputazione Abbazia di Collemaggio, L'Aquila.

Garzella G, 1990: Pisa com'era: topografia e insediamento dall'impianto tardoantico alla città murata del secolo XII, GISEM, Naples.

Giuntella AM, 1994: L'alto Medioevo in Abruzzo alla luce dell'archeologia, in Francovich R \& Noyè G (ed.), La Storia dell'alto Medioevo italiano (VI-X secolo) alla luce dell'archeologia, Atti del Convegno Internazionale: 231-49. All'Insegna del Giglio, Florence.

Giuntella AM, 1999: Abruzzo e Molise, in Pergola P (ed.), Alle origini della parrocchia rurale (IV-VIII secolo), Atti della giornata tematica dei Seminari di Archeologia Cristiana: 388, PIAC, Vatican City.

Giuntella AM, 2001: Dieci anni di ricerche nel campo dell'Archeologia Cristiana in Abruzzo, in Russo E (ed.), Dieci anni di nuove scoperte di Archeologia Cristiana in Italia, VII Convegno Nazionale di Archeologia Cristiana: 571-606. Centro Editoriale di Ateneo, Cassino.

Giuntella AM, 2002: Brevi note in margine al santuario di S. Vittorino in Amiternum, in Celentano MS (ed.): TEPUI $\Sigma$ in ricordo di Maria Laetitia Coletti: 313-40. Edizioni dell'Orso, Alessandria.

Giuntella AM, 2003: Il Ducato di Spoleto: persistenze e trasformazioni nell'assetto territoriale (Abruzzo e Sabina), in I Longobardi dei Ducati di Spoleto e Benevento, Atti del XVI Convegno Internazionale di Studi sull'Alto Medioevo: 763-99. CISAM, Spoleto.

Giustizia F, 2007: Peltuinum. La storia di uno scavo e il palinsesto culturale della chiesa di S. Paolo, in Clementi A (ed.), I campi aperti di Peltuinum dove tramonta il sole: 207-43. Deputazione Abbazia di Collemaggio, L'Aquila.

Martellone A, 2007: Alcune considerazioni sulla mansio di Bazzano, in Clementi A (ed.), I campi aperti di Peltuinum dove tramonta il sole: 190-201. Deputazione Abbazia di Collemaggio, L'Aquila.

Milanese M, (ed.) 2003: Uchi Maius tardo antica e islamica, Miscellanea di studi 1997-2002: 40-41, 285-352. PLUS, Pisa.

Pani Ermini L, 1972: Contributi alla storia della diocesi di Amiternum, Forcona e Aveia nell'Alto Medioevo, Rendiconti della Pontificia Accademia Romana di Archeologia, 3 (44), 264-73.

Pani Ermini L, 1975: Il santuario del Martire Vittorino in Amiternum e la sua catacomba, Nuovo poligrafico Alterocca, Terni.

Pani Ermini L, 1976: Il santuario di S. Vittorino in Amiternum. Note sulla sua origine, Rivista di Archeologia, 3, 95-105.

Pani Ermini L, 1978: Decorazione architettonica e suppellettile liturgica in Abruzzo nell'alto Medioevo, in L'Architettura in Abruzzo e Molise dall'antichità alla fine del XVIII secolo, Atti del XIX Congresso di Storia dell'Architettura: 67-76. Ferri, L'Aquila.

Pani Ermini L, 1979: Echi e tradizioni diverse nella scultura altomedievale in Abruzzo, Abruzzo, 14 (1), 41-60.

Pani Ermini L, 1987: Il territorio di Amiternum nella tarda antichità e nell'altomedioevo, in La terra di Pizzoli tra alto medioevo e sec. XV, Giornata di Studio in onore di Ambrogio da Pizzoli, discepolo di S. Giovanni da Capestrano: 33-54. Colacchi, L'Aquila.

Patitucci S, 2001: Evidenze archeologiche della provincia Maritima bizantina in Toscana, in Rotili M (ed.), Società multiculturali nei secoli V-IX, Atti delle VII giornate di studio sull'età romano-barbarica (Benevento 1999): 191-222. Arte Tipografica, Naples.

Patitucci S, 2004a: La toponomastica come fonte della topografia medievale: l'esempio della Tuscia bizantina, in Laudizi G \& Marangio C (ed.), Studi in memoria di Ciro Santoro: 135-58. Congedo, Lecce.

Patitucci S, 2004b: La via Francigena in Toscana, in Patitucci S (ed.), La via francigena e altre strade della Toscana medievale: 9-136. All'Insegna del Giglio, 
Florence.

Redi F, 2007: Domitilla, Vittorino ed Equizio: aspetti e problemi della cristianizzazione in territorio aquilano dagli scavi di San Paolo di Barete e di San Basilio in L'Aquila, in Bonacasa Carra RM \& Vitale E (ed.), La cristianizzazione in Italia fra Tardoantico e Altomedioevo, IX Congresso Nazionale di Archeologia Cristiana: 895-914. Saladino, Palermo.

Redi F, 2009: Archeologia dei paesaggi medievali e popolamento dell'Abruzzo interno tra la tarda antichità e la rifondazione della città dell'Aquila nella seconda metà del sec. XIII, in Macchi Janica G (ed.), Geografia del popolamento. Casi di studio, metodi e teorie, Atti della Giornata di Studi: 21-30. Edizioni dell'Università, Siena.

Redi F, 2010: Produzione Lapidaria, in Roma G. (ed.), I Longobardi del Sud: 141-73. Giorgio Bretschneider, Rome.

Redi F \& A Forgione (ed.) 2014: La chiesa di S. Paolo di Barete $(A Q)$. Dallo scavo al restauro. Venti secoli di storia riscoperti, All'Insegna del Giglio, Florence.

Redi F \& C lovenitti 2006: Piana S. Marco, Comune di Castel del Monte (AQ). Gli scavi dell'anno 2004, Archeologia Medievale, 33, 307-23.

Redi F \& C Malandra 2004: Piana e Colle S. Marco, Comune di Castel del Monte (AQ). Notizie preliminari alla campagna di scavo 2003, Archeologia Medievale, 31, 229-43.

Redi F \& F Savini (in press): Luoghi di culto e cimiteri fra tarda antichità e medioevo nell'alta valle dell'Aterno (AQ). Un aggiornamento delle ricerche, in Ebanista C \& Rotili M, Luoghi di culto, necropoli e prassi funeraria fra tarda antichità e medioevo, Atti del Convegno.

Redi F, A de lure \& L Di Blasio 2012: Amiternum, Forcona, Peltuinum, Aufinum e il loro territorio fra tarda antichità e altomedioevo: analisi toponomastica e archeologica, in Redi F \& Forgione A (ed.), VI Congresso Nazionale di Archeologia Medievale: 342-46. All'Insegna del Giglio, Florence.

Redi F, A de lure \& E Siena 2012: L’Abruzzo tra Goti e Bizantini. Aggiornamenti della ricerca archeologica, in Ebanista C \& Rotili M (ed.), Le trasformazioni del mondo romano e le grandi migrazioni. Nuovi popoli dall'Europa settentrionale e centro-orientale alle coste del Mediterraneo, Atti del Convegno Internazi- onale di Studi: 195-216. Tavolario, Cimitile.

Redi F, E Siena, L Meloni \& T Di Pietro 2012: Produzioni e consumi nell'Abruzzo interno tardoantico e altomedievale, in Redi F \& Forgione A (ed.): VI Congresso Nazionale di Archeologia Medievale: 595-600. All'Insegna del Giglio, Florence.

Redi F, A Forgione, F Savini, A Russi, E Siena \& A de lure (in press): Amiternum (AQ). Scavo archeologico in località "Campo S. Maria”: relazione preliminare, scavo 2013, Archeologia Medievale, 41.

Redi F, A Forgione, F Savini, E Siena, A de lure \& E Ciammetti 2013: Amiternum (AQ), “Campo S. Maria”, rapporto preliminare 2012, Archeologia Medievale, 40, 267-86.

Rotili M, 1992-1993: Due rinvenimenti di età romanobarbarica, Romanobarbarica, 12, 393-404.

Scrinari VSM, 1978: Note di archeologia paleocristiana abruzzese, in Atti del IX Congresso internazionale di Archeologia cristiana, Roma, 21-27 settembre 1975: 467-69. PIAC, Vatican City.

Somma, MC 2012: Il santuario di S. Vittorino ad Amiternum: formazione e trasformazioni di uno spazio cultuale, in Coscarella A \& P De Santis (ed.), X Congresso Nazionale di Archeologia Cristiana: Martiri, Santi, patroni per una archeologia della devozione, Atti del congresso 2010: 185-94. Università della Calabria, Arcavacata di Rende.

Tartara P, 2007: Il territorio aquilano lungo il tratturo regio. Primi dati per una carta archeologica sistematica (Area tra Bazzano e Capestrano), in Clementi A (ed.), I campi aperti di Peltuinum dove tramonta il sole: 449-565. Deputazione Abbazia di Collemaggio, L'Aquila.

Tulipani L, 1996: Da Peltuinum alla Civita Ansidonia, in Campanelli $A$, (ed.), Peltuinum, antica città sul tratturo: 50-61. Carsa Edizioni, Pescara.

Tuteri R, 2014: Il territorio amiternino nella tarda romanità. Appunti, in Redi F \& A Forgione (ed.), La chiesa di S. Paolo di Barete (AQ). Dallo scavo al restauro. Venti secoli di storia riscoperti: 13-34. All'Insegna del Giglio, Florence. 